\title{
Impact of Mahatma Gandhi National Rural Employment Guarantee Act on Enhancing Socio-economic Conditions of Rural Households
}

\author{
Mousam Kumari ${ }^{1}$, Ramesh Chandra Rai ${ }^{2}$, A K Paswan ${ }^{3}$ \\ ${ }^{1}$ Ph.D. Scholar, University Department of Political Science, Tilka Manjhi Bhagalpur University, Bhagalpur, \\ Bihar, India \\ ${ }^{2}$ University Professor and Head, University Department of Political Science, Tilka Manjhi Bhagalpur \\ University, Bhagalpur, Bihar, India \\ ${ }^{3}$ Assistant Professor, Department of Extension Education, Tirhut College of Agricultural, Dholi, Muzaffarpur, \\ Bihar, India
}

Corresponding Author: Mousam Kumari

\begin{abstract}
Employment is fundamental pre-requisite to raise per capita income and eradicate household poverty. After independence and particularly from the Fifth Five Year Plan onwards, Government of India has initiated several rural development programmes for raising rural employment for the alleviation of rural poverty. The present study was carried out over 240 respondents in Samastipur district of Bihar to find out Impact of MGNREGA on the socioeconomic conditions of the rural people. The study revealed that the impact of the Act has been found to be of medium level as have been reported by $52.92 \%$ of the beneficiaries. The components wise impact in terms of economic, social, health, psychological, environmental, infrastructural and institutional impact were evaluated. The results revealed that under economic impact employment in agricultural lean period with the mean score value of $2.64 \%$ observed first and under social impact the substantial impact have been recorded in the area of increased social mobility. In case of impact on health and hygiene, majority of male beneficiaries $(46.67 \%)$ represent that there was a substantial impact on improvement in the nutritional security. While in case of psychological, environmental, infrastructural and institutional impact was found in the thought is being developed to become selfemployed in near future, conservation of natural resources, enhanced rural connectivity and
\end{abstract}

strengthening grass-root democracy,
respectively.

Key words: Impact, MGNREGA, Socioeconomic conditions, Beneficiaries

\section{INTRODUCTION}

In general after independence and particularly from the fifth five year plan onwards, Government of India has been taken several initiatives to raising rural employment for the alleviation of rural poverty. Despite all these endeavours, the unemployment in general and rural unemployment in particular has remained one of the important issues of rural development. NREGA, renamed on second October, 2009 as Mahatma Gandhi National Rural Employment Guarantee Act (MGNREGA), is one of the largest rightsbased social protection initiatives in the world. The NREGS were launched by the UPA government in 2004 in 200 backward districts and later on extended to the entire districts in the country in 2008. The National Rural Employment Guarantee Act was enacted in 2005 to provide a minimum of 100 days guaranteed wage employment in every financial year to rural households with unemployed adult members prepared to do unskilled manual work. NREGA is the first ever law; internationally that 
guarantees wage employment act at an unprecedented scale. The programme has world's largest financial inclusion for providing poor people access to the formal banking system. MGNREGA is therefore, different from the other earlier Government employment schemes, since it treats employment as right and is intended to be demand-driven. The MGNREGS is a holistic measure aimed at fulfilling one of the most important Human Rights that is Right to Employment at least to one member of the family. The main objective of MGNREGS is the creation of durable assets and strengthening the livelihood resource base of the rural poor for fighting poverty. Rekha and Mehta (2019) observed significant changes in the socio-economic variables and opined that MGNREGA can efficiently contribute towards the economic growth. Sarkar et al. (2011) reported that remarkable changes have observed in the socio-economic attributes viz., per capita income on food expenditure, expenditure on child education, savings, access of facility to healthcare and possession of assets for those households which are regularly working in the MGNREGA scheme. As the access to food and appropriate shelter, economic status, social values are mainly depends upon the income level (Pillai and Nithya, 2014). Kharakwal and Kumar (2015) noticed that the value of socio-economic index revealed that in the initial stages of implementation of the programme, about $36 \%$ of the beneficiaries households were in lower socio-economic strata which decreased to $12 \%$ in 2013-14, while beneficiary households in better socioeconomic strata increased from 30 to $55 \%$. To assess the socio-economic impact of the scheme in partial manner, a composite socio- economic index including all relevant aspects will be more fruitful in evaluating overall impact of the programme. Keeping these view in mind the study focused on impact of the MGNREGA on the socioeconomic conditions of the rural households.

\section{MATERIALS AND METHODS}

The study was carried out in the purposively selected Pusa block of Samastipur district of Bihar. There are 20 blocks in Samastipur district. Out of these Pusa block has been purposively selected for this study. Further, five Panchayats have been chosen by following the random sampling technique. From each Panchayat, two villages were selected following the same criteria. In this way, the locales of the study were ten villages selected from five Panchayat of Pusa block of Samastipur district. For selection of respondents, a total of 24 respondents consisting of 12 male and 12 female MGNREGA card holders selected by following the random sampling technique. In this way the sample respondent of the study will consist of 120 male and 120 female MNREGA beneficiaries/card holders. The data were collected through personal interview with the help of pre structured schedule. The data were analyzed with the help of frequency distribution, mean and standard deviation.

\section{RESULTS AND DISCUSSION Overall impact of the MGNREGA on the socio-economic conditions of the rural people}

The data presented in table 1 revealed that the impact of the Act has been found to be of medium level as it has been reported by $52.92 \%$ of the beneficiaries of the Act. On the other hand $27.50 \%$ has found the scheme as of creating high impact. Further only $19.58 \%$ beneficiaries perceived the scheme as creating low impact on them. On the basis of this figure it can be concluded that the Act has more or less succeeded in achieving its objective not fully but partially to the greater side.

Table 1. Overall level of impact of the Act on the MGNREGA beneficiaries

\begin{tabular}{|l|l|l|l|l|l|l|}
\hline \multirow{2}{*}{ Category } & \multicolumn{2}{|l|}{ Male $(\mathbf{n = 1 2 0})$} & \multicolumn{2}{l|}{ Female $(\mathbf{n = 1 2 0})$} & \multicolumn{2}{l|}{ Total $(\mathbf{n = 2 4 0})$} \\
\cline { 2 - 7 } & $\mathbf{f}$ & $\mathbf{\%}$ & $\mathbf{f}$ & $\mathbf{\%}$ & $\mathbf{f}$ & \% \\
\hline Low & 31 & 25.83 & 16 & 13.33 & 47 & 19.58 \\
\hline Medium & 62 & 51.67 & 65 & 54.17 & 127 & 52.92 \\
\hline High & 27 & 22.50 & 39 & 32.50 & 66 & 27.50 \\
\hline
\end{tabular}

The gender wise assessment of impact of the Act shows that women have 
greatly been benefitted by the Act as compared to their counterpart. Other beneficiaries $32.50 \%$ of women have found it of high impact and 13.33 per cent as of low impact. As compared to women beneficiaries male beneficiaries have not been benefited by the Act as $51.67 \%$ of them have perceived the Act as of medium impact followed by $22.50 \%$ as of high impact. Hence the study concluded that the Act has created were greater impact on female beneficiaries as compared to the male beneficiaries. Malangmeih et al. (2014) also reported similar results.

\section{Economic impact of the Act}

Table 2. Economic impact of the Act

\begin{tabular}{|c|c|c|c|c|c|c|c|c|c|}
\hline \multirow{4}{*}{ S.N } & \multirow[t]{3}{*}{ Economic impact } & \multicolumn{6}{|c|}{ Degree of impact } & \multirow[t]{2}{*}{$\mathrm{N}=\mathbf{2 4 0}$} & \multirow[t]{4}{*}{ Rank } \\
\hline & & \multicolumn{3}{|c|}{ Male $(n=120)$} & \multicolumn{3}{|c|}{ Female $(n=120)$} & & \\
\hline & & Sub. & Good & Poor & Sub. & Good & Poor & \multirow{2}{*}{$\begin{array}{l}\text { Total Mean } \\
\text { score }\end{array}$} & \\
\hline & Statement & $f(\%)$ & $\mathbf{f}(\%)$ & $\mathbf{f}(\%)$ & $\mathbf{f}(\%)$ & $f(\%)$ & $f(\%)$ & & \\
\hline 1. & Enhanced livelihood security & $\begin{array}{l}18 \\
(15.00)\end{array}$ & $\begin{array}{l}54 \\
(45.00)\end{array}$ & $\begin{array}{l}48 \\
(40.00)\end{array}$ & $\begin{array}{l}75 \\
(62.50)\end{array}$ & $\begin{array}{l}24 \\
(20.00)\end{array}$ & $\begin{array}{l}21 \\
(17.50)\end{array}$ & 2.100 & $\mathbf{V}$ \\
\hline 2. & Reduction in indebtness & $\begin{array}{l}28 \\
(23.33)\end{array}$ & $\begin{array}{l}62 \\
(51.67)\end{array}$ & $\begin{array}{l}30 \\
(25.00)\end{array}$ & $\begin{array}{l}58 \\
(48.33)\end{array}$ & $\begin{array}{l}36 \\
(30.00)\end{array}$ & $\begin{array}{l}26 \\
(21.67)\end{array}$ & 2.125 & IV \\
\hline 3. & Enhanced purchasing power & $\begin{array}{l}84 \\
(70.00)\end{array}$ & $\begin{array}{l}26 \\
(21.67)\end{array}$ & $\begin{array}{l}10 \\
(8.33)\end{array}$ & $\begin{array}{l}58 \\
(48.33)\end{array}$ & $\begin{array}{l}30 \\
(25.00)\end{array}$ & $\begin{array}{l}32 \\
(26.67)\end{array}$ & 2.417 & III \\
\hline 4. & $\begin{array}{l}\text { Improved economic status of the } \\
\text { family. }\end{array}$ & $\begin{array}{l}74 \\
(61.67)\end{array}$ & $\begin{array}{l}24 \\
(20.00)\end{array}$ & $\begin{array}{l}22 \\
(18.33)\end{array}$ & $\begin{array}{l}72 \\
(60.00)\end{array}$ & $\begin{array}{l}36 \\
(30.00)\end{array}$ & $\begin{array}{l}12 \\
(10.00)\end{array}$ & 2.467 & II \\
\hline 5. & $\begin{array}{l}\text { Employment in Agricultural lean } \\
\text { period }\end{array}$ & $\begin{array}{l}88 \\
(73.33)\end{array}$ & $\begin{array}{l}23 \\
(19.17)\end{array}$ & $\begin{array}{l}9 \\
(7.50)\end{array}$ & $\begin{array}{l}88 \\
(73.33)\end{array}$ & $\begin{array}{l}19 \\
(15.83)\end{array}$ & $\begin{array}{l}13 \\
(10.83)\end{array}$ & 2.642 & $\mathbf{I}$ \\
\hline 6. & Opening of bank account $1^{\text {st }}$ time & $\begin{array}{l}21 \\
(17.50)\end{array}$ & $\begin{array}{l}18 \\
(15.00)\end{array}$ & $\begin{array}{l}81 \\
(67.50)\end{array}$ & $\begin{array}{l}62 \\
(51.67)\end{array}$ & $\begin{array}{l}45 \\
(37.50)\end{array}$ & $\begin{array}{l}13 \\
(10.83)\end{array}$ & 1.954 & VI \\
\hline
\end{tabular}

Table 2, indicated that under the economic impact $45.00 \%$ of the male respondent reported that there is good impact regarding enhanced livelihood security, while $62.5 \%$ of the female beneficiaries reported that there was a substantial impact on this matter. Beneficiaries were feeling easy to run their family due to regular payment under MGNREGA. Out of six economic impact perceived by them, first rank was assigned by MGNREGA beneficiaries was employment in Agricultural lean period with the mean score value of 2.64 , the other impacts perceived by the beneficiaries in their descending order were, Improved economic status of the family, enhanced purchasing power, reduction in indebtness, Enhanced livelihood security , and opening of bank account $1^{\text {st }}$ time, improved economic status of the family, enhanced livelihood security with the mean score value $2.47,2.42,2.13,2.10$ and 1.95 respectively. Similar results have been reported by Pillai and Nithiya (2014) and Kharakwal and Kumar (2015)

\section{Social impact of the Act}

Table 3. Social impact of the Act

\begin{tabular}{|c|c|c|c|c|c|c|c|c|c|}
\hline \multirow[t]{4}{*}{ S.N } & \multirow[t]{4}{*}{ Social impact } & \multicolumn{6}{|c|}{ Degree of impact } & \multirow{4}{*}{$\begin{array}{l}(\mathrm{N}=240) \\
\text { Mean Score }\end{array}$} & \multirow{4}{*}{ Rank } \\
\hline & & \multicolumn{3}{|c|}{ Male $(n=120)$} & \multicolumn{3}{|c|}{ Female $(n=120)$} & & \\
\hline & & Sub. & Good & Poor & Sub. & Good & Poor & & \\
\hline & & $\mathbf{f}(\%)$ & $\mathbf{f}(\%)$ & $f(\%)$ & $\mathbf{f}(\%)$ & $\mathbf{f}(\%)$ & $\mathbf{f}(\%)$ & & \\
\hline 1. & Increased social mobility & $\begin{array}{l}98 \\
(81.67)\end{array}$ & $\begin{array}{l}20 \\
(16.67)\end{array}$ & $\begin{array}{l}2 \\
(1.67)\end{array}$ & $\begin{array}{l}56 \\
(46.67)\end{array}$ & $\begin{array}{l}36 \\
(30.00)\end{array}$ & $\begin{array}{l}28 \\
(23.33)\end{array}$ & 2.517 & II \\
\hline 2. & Children education possible & $\begin{array}{l}72 \\
(60.00)\end{array}$ & $\begin{array}{l}23 \\
(19.17) \\
\end{array}$ & $\begin{array}{l}25 \\
(20.83)\end{array}$ & $\begin{array}{l}74 \\
(61.67) \\
\end{array}$ & $\begin{array}{l}28 \\
(23.33) \\
\end{array}$ & $\begin{array}{l}18 \\
(15.00) \\
\end{array}$ & 2.429 & IV \\
\hline 3. & Enhancement in social status. & $\begin{array}{l}81 \\
(67.50)\end{array}$ & $\begin{array}{l}28 \\
(23.33)\end{array}$ & $\begin{array}{l}11 \\
(9.17)\end{array}$ & $\begin{array}{l}61 \\
(50.83)\end{array}$ & $\begin{array}{l}48 \\
(40.00)\end{array}$ & $\begin{array}{l}11 \\
(9.17)\end{array}$ & 2.500 & III \\
\hline 4. & $\begin{array}{l}\text { Reduced dependency upon the } \\
\text { village money lenders. }\end{array}$ & $\begin{array}{l}80 \\
(66.67)\end{array}$ & $\begin{array}{l}20 \\
(16.67)\end{array}$ & $\begin{array}{l}20 \\
(16.67)\end{array}$ & $\begin{array}{l}94 \\
(78.33)\end{array}$ & $\begin{array}{l}14 \\
(11.67)\end{array}$ & $\begin{array}{l}12 \\
(10.00)\end{array}$ & 2.592 & I \\
\hline 5. & Equal opportunity for women & $\begin{array}{l}70 \\
(58.33)\end{array}$ & $\begin{array}{l}26 \\
(21.67)\end{array}$ & $\begin{array}{l}24 \\
(20.00)\end{array}$ & $\begin{array}{l}55 \\
(45.83)\end{array}$ & $\begin{array}{l}31 \\
(25.83)\end{array}$ & $\begin{array}{l}34 \\
(28.33)\end{array}$ & 2.279 & $\mathbf{V}$ \\
\hline 6. & Migration check & $\begin{array}{l}62 \\
(51.67)\end{array}$ & $\begin{array}{l}36 \\
(30.00)\end{array}$ & $\begin{array}{l}22 \\
(18.33)\end{array}$ & $\begin{array}{l}40 \\
(33.33)\end{array}$ & $\begin{array}{l}52 \\
(43.33)\end{array}$ & $\begin{array}{l}23 \\
(19.17)\end{array}$ & 2.196 & VI \\
\hline
\end{tabular}


The table 3 stated that substantial impact was found in the area of increased social mobility, children education possible and enhancement in social status with the majority of $81.67,60.00$ and $67.50 \%$ of the male beneficiaries respectively. While, in the case of female beneficiaries, it was found $46.67 \%$, again 61.67 and $50.83 \%$, respectively. However, as per the mean score obtained for each impact, under social impact rank was assigned two. The first rank was assigned to the reduced dependency upon the village money lenders, having the mean score value 2.59 , followed by the other impacts in their descending order were increased social mobility, enhancement of social status, children education possible, equal opportunity for women and migration check with the mean score value 2.52, 2.50.2.43, 2.28 and 2.20, respectively. Similar observations were made by De and Bhattacharyya (2013) and Pankaj and Tankha (2010).

\section{Impact on health and hygiene}

MGNERGA has made good effect on the health and hygiene of the beneficiaries. After working under MGNERGA beneficiaries are now becoming able to enhance in the quality and quantity of food i.e. enhancement in the nutritional security, accessing for the medical facilities and being able to maintain sanitation. It is clear from table 4 , that under the category of impact on health and hygiene, majority of male beneficiaries $(46.67 \%)$ represent that there was a substantial impact on improvement in the nutritional security due to MGNREGA, while majority of $50.0 \%$ of female beneficiaries reported that substantial impact for this. Regarding accessing medical facility 51.67 and $45.00 \%$ of the male and female beneficiaries responded under the category of good and substantial impact, respectively.

However, mean score showed that the first rank was assigned to the improvement in nutritional security, having the mean score value of 2.35 followed by the other impacts, in order to their descending order were, i.e. accessing medical facility and enhanced sanitation, with the mean score value 2.01 and 1.85 respectively. Present findings are in the line of earlier observations of Arora et al. (2013) and Chella Basker (2013).

Table 4. Impact on health and hygiene

\begin{tabular}{|c|c|c|c|c|c|c|c|c|c|}
\hline \multirow{3}{*}{ S.N } & \multirow{3}{*}{ Impact on health and hygiene. } & \multicolumn{6}{|c|}{ Degree of impact } & \multirow{2}{*}{$\mathrm{N}=\mathbf{2 4 0}$} & \multirow{3}{*}{ Rank } \\
\hline & & \multicolumn{3}{|c|}{ Male $(\mathbf{n}=120)$} & \multicolumn{3}{|c|}{ Female $(n=120)$} & & \\
\hline & & Sub. & Good & Poor & Sub. & Good & Poor & $\begin{array}{ll}\text { Total } & \text { rank } \\
\text { score } & \end{array}$ & \\
\hline 1. & $\begin{array}{l}\text { Improvement in the nutritional } \\
\text { security. }\end{array}$ & $\begin{array}{l}56 \\
(46.67)\end{array}$ & $\begin{array}{l}44 \\
(36.67)\end{array}$ & $\begin{array}{l}20 \\
(16.67)\end{array}$ & $\begin{array}{l}60 \\
(50.00)\end{array}$ & $\begin{array}{l}50 \\
(41.67)\end{array}$ & $\begin{array}{l}10 \\
(8.33)\end{array}$ & 2.35 & I \\
\hline 2 & Enhanced sanitation & $\begin{array}{l}36 \\
(30.00) \\
\end{array}$ & $\begin{array}{l}48 \\
(40.00)\end{array}$ & $\begin{array}{l}36 \\
(30.00)\end{array}$ & $\begin{array}{l}24 \\
(20.00)\end{array}$ & $\begin{array}{l}36 \\
(30.00)\end{array}$ & $\begin{array}{l}60 \\
(50.00) \\
\end{array}$ & 1.85 & III \\
\hline 3 & Accessing medical facility & $\begin{array}{l}18 \\
(15.00)\end{array}$ & $\begin{array}{l}62 \\
(51.67) \\
\end{array}$ & $\begin{array}{l}40 \\
(33.33) \\
\end{array}$ & $\begin{array}{l}54 \\
(45.00) \\
\end{array}$ & $\begin{array}{l}38 \\
(31.67)\end{array}$ & $\begin{array}{l}28 \\
(23.33) \\
\end{array}$ & 2.01 & II \\
\hline
\end{tabular}

\section{Psychological impact}

Perusal of table 5 indicated, that under the psychological impact majority of the male beneficiaries $(85.00 \%)$, who reported, that there was a substantial impact in terms of thought is being developed to become self-employed in near future but among the female beneficiaries $66.67 \%$ impact was found substantial in minimization of social exploitation. However, as per the mean score obtained for each impact, rank was assigned to the psychological impact of MGNREGA. The first rank was assigned to the, thought is being developed to become self-employed in near future, with the mean score value 2.54 followed by the other impacts, in order to their descending order were, increased habit of money saving and minimization of social exploitation with the mean score value 2.25 and 2.13 respectively. Similar observations were made by Sarkar (2011). 
Mousam Kumari et.al. Impact of Mahatma Gandhi National Rural Employment Guarantee Act on enhancing socio-economic conditions of rural households.

Table 5. Psychological impact of the Act

\begin{tabular}{|c|c|c|c|c|c|c|c|c|c|}
\hline \multirow[t]{4}{*}{ S.N } & \multirow{4}{*}{ Psychological impact } & \multicolumn{6}{|c|}{ Degree of impact } & \multirow[t]{2}{*}{$\mathrm{N}=\mathbf{2 4 0}$} & \multirow{4}{*}{ Rank } \\
\hline & & \multicolumn{3}{|c|}{ Male $(n=120)$} & \multicolumn{3}{|c|}{ Female $(n=120)$} & & \\
\hline & & Sub. & Good & Poor & Sub. & Good & Poor & \multirow{2}{*}{$\begin{array}{l}\text { Total Mean } \\
\text { score }\end{array}$} & \\
\hline & & $\begin{array}{l}\mathrm{f} \\
(\%)\end{array}$ & $\begin{array}{l}\mathrm{f} \\
(\%)\end{array}$ & $\begin{array}{l}\mathrm{f} \\
(\%)\end{array}$ & $\begin{array}{l}\mathrm{f} \\
(\%)\end{array}$ & $\begin{array}{l}\mathrm{f} \\
(\%)\end{array}$ & $\begin{array}{l}f \\
(\%)\end{array}$ & & \\
\hline 1. & Increased habit of money saving. & $\begin{array}{l}68 \\
(56.67) \\
\end{array}$ & $\begin{array}{l}34 \\
(28.33)\end{array}$ & $\begin{array}{l}18 \\
(15.00)\end{array}$ & $\begin{array}{l}56 \\
(46.67)\end{array}$ & $\begin{array}{l}20 \\
(16.67)\end{array}$ & $\begin{array}{l}44 \\
(36.67)\end{array}$ & 2.25 & II \\
\hline 2. & $\begin{array}{l}\text { Thought is being developed to become } \\
\text { self-employed in near future. }\end{array}$ & $\begin{array}{l}102 \\
(85.00)\end{array}$ & $\begin{array}{l}8 \\
(6.67) \\
\end{array}$ & $\begin{array}{l}10 \\
(8.33) \\
\end{array}$ & $\begin{array}{l}58 \\
(48.33) \\
\end{array}$ & $\begin{array}{l}42 \\
(35.00)\end{array}$ & $\begin{array}{ll}20 \\
(16.67)\end{array}$ & 2.54 & I \\
\hline 3. & Minimization of social exploitation & $\begin{array}{l}26 \\
(21.67)\end{array}$ & $\begin{array}{l}42 \\
(35.00)\end{array}$ & $\begin{array}{l}52 \\
(43.33) \\
\end{array}$ & $\begin{array}{l}80 \\
(66.67)\end{array}$ & $\begin{array}{l}18 \\
(15.00)\end{array}$ & $\begin{array}{ll}22 \\
(18.33)\end{array}$ & 2.13 & III \\
\hline
\end{tabular}

\section{Environmental impact of the Act}

The table 6 , revealed that under the environmental impact, majority of the male beneficiaries $(81.67 \%)$ expressed the substantial impact in terms of conservation of natural resources, while for the same aspect, $68.33 \%$ of female beneficiaries expressed substantial impact. Equal percentage $(43.33 \%)$ of the male and female beneficiaries was substantial impact had been found on the added village beautification. Similar results were reported by Karthika (2015). However, De and Jana (2013) and Thomas and Bhatia (2012) reported dissatisfaction about the impact of MGNREGA on the quality of the work performed under this scheme.

Table 6. Environmental impact of the Act

\begin{tabular}{|c|c|c|c|c|c|c|c|c|c|}
\hline \multirow[t]{4}{*}{ S.N } & \multirow[t]{4}{*}{ Environment-al impact. } & \multicolumn{6}{|c|}{ Degree of impact } & \multirow{4}{*}{$\begin{array}{l}\mathrm{N}=240 \\
\text { Total Mean score }\end{array}$} & \multirow{4}{*}{ Rank } \\
\hline & & \multicolumn{3}{|c|}{ Male $(\mathbf{n}=120)$} & \multicolumn{3}{|c|}{ Female $(n=120)$} & & \\
\hline & & Sub. & Good & Poor & Sub. & Good & Poor & & \\
\hline & & $\begin{array}{l}\mathbf{f} \\
(\%)\end{array}$ & $\begin{array}{l}\mathbf{f} \\
(\%)\end{array}$ & $\begin{array}{l}\mathbf{f} \\
(\%)\end{array}$ & $\begin{array}{l}\mathbf{f} \\
(\%)\end{array}$ & $\begin{array}{l}\mathbf{f} \\
(\%)\end{array}$ & $\begin{array}{l}\mathbf{f} \\
(\%)\end{array}$ & & \\
\hline 1. & Added village beautification & $\begin{array}{l}52 \\
(43.33)\end{array}$ & $\begin{array}{l}40 \\
(33.33)\end{array}$ & $\begin{array}{l}28 \\
(23.33)\end{array}$ & $\begin{array}{l}52 \\
(43.33)\end{array}$ & $\begin{array}{l}42 \\
(35.00)\end{array}$ & $\begin{array}{l}26 \\
(21.67)\end{array}$ & 2.21 & II \\
\hline 2. & Conservation of natural resources & $\begin{array}{l}98 \\
(81.67)\end{array}$ & $\begin{array}{l}12 \\
(10.00)\end{array}$ & $\begin{array}{l}10 \\
(8.33)\end{array}$ & $\begin{array}{l}82 \\
(68.33) \\
\end{array}$ & $\begin{array}{l}26 \\
(21.67)\end{array}$ & $\begin{array}{l}12 \\
(10.00)\end{array}$ & 2.66 & I \\
\hline
\end{tabular}

Infrastructural impact of the Act

The second prime objective of MGNREGA is the creation of rural infrastructure. Those changes/effects of MGNREGA which accelerated the rural infrastructure grouped in to infrastructural impact.

Perusal of table 7 indicated that under the infrastructural impact, in terms of creation of varieties of rural assets, only $18.33 \%$ of the male beneficiaries reported for the substantial impact, while among female beneficiaries, majority $75 \%$ of them reported for the same aspect. Majority of the male $(58.3 \%)$ and female $(58.3 \%)$ beneficiaries opined for the subject of enhanced rural connectivity.

\begin{tabular}{|c|c|c|c|c|c|c|c|c|c|}
\hline \multirow[t]{4}{*}{ S.N } & \multirow{4}{*}{ Infrastructural Impact } & \multicolumn{6}{|c|}{ Degree of impact } & \multirow{4}{*}{$\begin{array}{l}\mathrm{N}=240 \\
\text { Total } \\
\text { Mean score }\end{array}$} & \multirow{4}{*}{ Rank } \\
\hline & & \multicolumn{3}{|c|}{ Female $(n=120)$} & \multicolumn{3}{|c|}{$\operatorname{Male}(\mathbf{n}=120)$} & & \\
\hline & & Sub. & Good & Poor & Sub. & Good & Poor & & \\
\hline & & $f(\%)$ & $\mathbf{f}(\%)$ & f(\%) & $f(\%)$ & $f(\%)$ & $f(\%)$ & & \\
\hline 1. & Creation of rural assets. & $\begin{array}{l}22 \\
(18.33)\end{array}$ & $\begin{array}{l}44 \\
(36.67)\end{array}$ & $\begin{array}{l}54 \\
(45.00)\end{array}$ & $\begin{array}{l}90 \\
(75.00)\end{array}$ & $\begin{array}{l}20 \\
(16.67)\end{array}$ & $\begin{array}{l}10 \\
(8.33) \\
\end{array}$ & 2.20 & II \\
\hline 2. & Enhanced rural connectivity. & $\begin{array}{l}70 \\
(58.33)\end{array}$ & $\begin{array}{l}30 \\
(25.00)\end{array}$ & $\begin{array}{l}20 \\
(16.67)\end{array}$ & $\begin{array}{l}70 \\
(58.33)\end{array}$ & $\begin{array}{l}40 \\
(33.33)\end{array}$ & $\begin{array}{l}10 \\
(8.33)\end{array}$ & 2.46 & $\mathbf{I}$ \\
\hline
\end{tabular}

\section{Institutional impact of the Act}

All those effects which bring about changes at the institutional level, grouped into institutional impact. MGNREGA has made institutional impact by strengthening grass root democracy and by creating space for civil society organizations. Table 8 showed details about of institutional impact. From the results it is clear that, majority of the beneficiaries i.e. $88.33 \%$ of male and $53.33 \%$ female leaded, for the substantial impact on strengthening grass root democracy. 
Mousam Kumari et.al. Impact of Mahatma Gandhi National Rural Employment Guarantee Act on enhancing socio-economic conditions of rural households.

Table 8. Institutional impact of the Act

\begin{tabular}{|c|c|c|c|c|c|c|c|c|c|}
\hline \multirow{3}{*}{ S.N } & \multirow{3}{*}{$\begin{array}{l}\text { Institutional } \\
\text { Impact }\end{array}$} & \multicolumn{6}{|c|}{ Degree of impact } & \multirow{3}{*}{$\begin{array}{l}\text { Total Mean } \\
\text { score }\end{array}$} & \multirow{3}{*}{ Rank } \\
\hline & & \multicolumn{3}{|c|}{ Male $(\mathrm{N}=120)$} & \multicolumn{3}{|c|}{ Female $(\mathrm{N}=120)$} & & \\
\hline & & Sub & Good & Poor & Sub & Good & Poor & & \\
\hline 1. & Strengthening gross root democracy & $\begin{array}{l}106 \\
(88.33)\end{array}$ & $\begin{array}{l}14 \\
(11.67)\end{array}$ & $\begin{array}{l}0 \\
(0.00)\end{array}$ & $\begin{array}{l}60 \\
(50.00)\end{array}$ & $\begin{array}{l}34 \\
(28.33)\end{array}$ & $\begin{array}{l}26 \\
(21.67)\end{array}$ & 2.58 & $\mathbf{I}$ \\
\hline 2. & $\begin{array}{l}\text { Creating space for civil society } \\
\text { organization }\end{array}$ & $\begin{array}{l}82 \\
(68.33) \\
\end{array}$ & $\begin{array}{l}26 \\
(21.67) \\
\end{array}$ & $\begin{array}{l}12 \\
10.00)\end{array}$ & $\begin{array}{l}60 \\
(50.00) \\
\end{array}$ & $\begin{array}{l}32 \\
(26.67) \\
\end{array}$ & $\begin{array}{l}24 \\
(20.00) \\
\end{array}$ & 2.43 & II \\
\hline
\end{tabular}

Strengthening grass root democracy is one of the major institutional impacts. The program implementation has been entrusted to Panchayati Raj Institutions which are the main planning and implementing authorities, Gram Sabha have been assigned a pivotal role in planning, monitoring and social audit of project under MGNREGA. There was the substantial institutional impact, regarding creating space for civil society organization (68.33 $\%)$, followed by good and poor impact, in this subject with the 21.67 and $10.00 \%$, respectively among the male beneficiaries, while among the female beneficiaries it was found 50.00, 26.67 and 20.00 per cent respectively in the category of substantially, good and poor institutional impact.

\section{CONCLUSION}

The study finally concluded that impact on the whole was considered as satisfactory. Thus, MGNREGA is working as a safety net for their livelihood. As a result of multifarious impact of MGNREGA i.e., economic impact, social impact, impact on health and hygiene, psychological impact, environmental impact, infrastructural impact and institutional impact which were directly or indirectly helped these beneficiaries for their wellbeing in particular and grass root development in general. Therefore study of the MGNREGA scheme conducted on the priority basis to know the impact of the Act on the beneficiaries.

\section{REFERENCES}

1. Arora, V., Kulshreshtra, L.R. and Upadhyay, V. 2013. Mahatma Gandhi National Rural Employment Guarantee Scheme: A unique scheme for Indian rural women. International Journal of Economic Practices and Theories, 3(2): 108-114.
2. Chella Basker, V.D. 2013. Socio-economic impact of MGNREGA in Coimbatore district of Tamil Nadu. Global Journal for Research Analysis, 2(12): 1-2.

3. De, B. and Jana, S. 2013. Implementation of MGNREGA in rural West Bengal: A case study of Sonamukhi block, Bankura district, West Bengal. Asian Journal of Multidimensional Research. 2(6): 17-30.

4. De, U.K. and Bhattacharyya, P. (2013). Participation of women in MGNREGA: How far is it successful in Morigaon, Assam. Indian Journal of Economics Development, 1(2): 38-48.

5. Karthika, K.T. 2015. Impact of MGNREGA on socio-economic development and women empowerment. Journal of Business and Management, 17(7): 16-19.

6. Kharkwal, S. and Kumar, A. 2015. Socioeconomic impact of MGNREGA: Evidences from district of Udham Singh Nagar in Uttarakhand, India. Indian Journal of Economics and Development 3(12): 1- 10.

7. Malangmeih, L., Bhattacharyya, K. and Mitra, A. 2014. Impact of MGNREGA on livelihood security of rural households: A case study in Bankura district of West Bengal state, India. Economic Affairs 59(2): 137-146.

8. Pankaj, A. and Tankha, R. 2010. Employment effects of the NREGS on women workers: A study in four states. Economic and Political Weekly, 45(30): 4555.

9. Pillai, A.B.A. and Nithiya, D. 2014. Socioeconomic conditions of MGNREGA programme workers in Krishnarayapuram taluk of Karur district. International Journal of Management Research and Review 4(9): 932-939.

10. Rekha and Mehta, R. 2019. Impact of MGNREGA in improving socio-economic status of rural people: A study of Jodhpur district of Rajasthan. International Journal of Humanities and Social Science Invention 8(3): $18-24$. 
Mousam Kumari et.al. Impact of Mahatma Gandhi National Rural Employment Guarantee Act on enhancing socio-economic conditions of rural households.

11. Sarkar, P. 2011. Socio-economic impact of MGNREGA in Burdwan district of West Bengal. M.Sc. Thesis submitted to G.B.P.U.A \& T, Pantnagar.

12. Sarkar, P., Kumar, J. and Supriya 2011. Impact of MGNREGA on reducing rural poverty and improving socio-economic status of rural poor: A study in Burdwan district of West Bengal. Agricultural Economics Research Review 24: 437-448.

13. Thomas, B. and Bhatia, R. 2012. Impact of NREGA scheme: A study on the overall quality of life of its beneficiaries. Asia Pacific Journal of Social Sciences, 4(2): 213-227.

How to cite this article: Kumari M, Rai RC, Paswan AK. Impact of Mahatma Gandhi National Rural Employment Guarantee Act on enhancing socio-economic conditions of rural households. International Journal of Research and Review. 2021; 8(2): 100-106. 